\title{
What is the real cost of our food? Implications for the environment, society and public health nutrition
}

\author{
Gabrielle O'Kane* \\ Faculty of Education, University of Canberra, Bruce, ACT 2601, Australia
}

Submitted 30 September 2010: Accepted 12 May 2011: First published online 7 July 2011

\begin{abstract}
The current, globalised food system supplies 'cheap' food to a large proportion of the world's population, but with significant social, environmental and health costs that are poorly understood. The present paper examines the nature and extent of these costs for both rural and urban communities, by illustrating the financial pressures on food producers and manufacturers to produce cheap food, the disconnection people experience with how and where their food is produced, and the rise in obesity levels that plague the globe. The paper then proposes that community food systems may play an important role in mitigating the adverse environmental, economic and social effects of the dominant food system, by the use of more sustainable food production methods, the development of local economies and enabling closer connections between farmers and consumers. There are many opportunities for public health nutritionists to contribute to the local food system literature to ascertain whether these systems improve inequities, provide better access to healthy food and help stem the tide of rising global obesity levels. Public health nutritionists can play a key role in supporting people to become food citizens and to advocate for democratic and sustainable food systems.
\end{abstract}

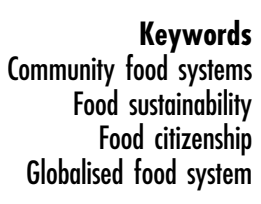

'Food sustainability' has become a critical issue in the agricultural and environmental sciences and public health nutrition in the context of population growth, rising obesity levels, climate change and the environmental degradation that occurs as a consequence of the modern food system $^{(1-5)}$. The food and nutrition system is defined as ${ }^{(6)}$ :

the set of operations and processes involved in transforming raw materials into foods and transforming nutrients into health outcomes, all of which functions as a system within biophysical and sociocultural contexts. (p. 853)

Human and natural resources form the basis of the food and nutrition system, but technology, policies, economics, education, socio-cultural trends and research also affect the way the food system operates ${ }^{(5)}$. Traditionally, nutritionists have been expert in their understanding of the role of nutrients in human health, but they also need to consider the broader context of human health, which also encompasses planetary health ${ }^{(7,8)}$. Health and nutrition professionals require a solid understanding of the environmental, social and health impact of our current food system, because health risks to populations arise from physical and cultural landscapes and from the impact that man has on environmental assets and systems ${ }^{(9)}$.

The aim of the present paper is to examine the real cost of food to the environment and population health, predominantly in the Western world, in the interest of conciseness. It begins by tracing the historical development of the modern food system, including a discussion of power relationships within this system. The paper then outlines the impact on the environment and evaluates the social and health costs that are the unintended consequences of this system. Finally, the paper considers current knowledge of the ways in which local food systems can mitigate the environmental, social and economic impact of our current food system that may also improve people's nutritional health and argues that public health nutrition can make a valuable contribution to this emerging literature.

\section{Upstream influences on the current food system}

\section{Globalisation}

The current global food system faces major challenges in being able to produce sufficient food for a growing world population that addresses the economic, environmental and social imperatives of sustainability. In the last four decades, the modern industrialised food system has been extremely successful in achieving a doubling of world food production, which has kept pace with world population growth ${ }^{(1,3)}$. However, these increases have not been uniform across the globe. It seems extraordinary that there are in excess of 800 million people who go 
hungry, mostly in the developing world, while there are others suffering from chronic disease as a result of overconsumption $^{(3,10,11)}$. Much of the growth in obesity and chronic disease is now occurring in developing countries undergoing a 'nutrition transition', where consumption of foods high in fats and sugars is rising, driven by urbanisation and globalisation, replacing traditional starchy, high-fibre staples ${ }^{(12,13)}$. With global population projections at $50 \%$ higher than the current 6 billion people by 2050 , the demand for grain is expected to double, owing to expected increases in per capita real income and further shifts in dietary patterns that will include more grain-fed meat ${ }^{(1)}$.

To achieve high production rates, agriculture became more mechanised from 1930 onwards, which led to reliance on finite stores of fossil fuels to run large machinery, pumped irrigation systems and produce artificial, nitrogen fertilisers $^{(3,14,15)}$. With increasing mechanisation has come larger farms and fewer farmers ${ }^{(3,16)}$. In an attempt to gain production efficiencies, farmers now grow specialised crops, such that four main grains - barley, maize, rice and wheat - occupy nearly $40 \%$ of global cropland ${ }^{(10)}$.

\section{Power and politics in the globalised food system}

The industrialised food system that has given rise to these increases in production and inequities has been developing for centuries, but it has been since the Bretton Woods conference in 1944, where Western leaders designed a new economic and financial structure, that a new era of global food trade started to emerge. Three supranational institutions - the World Bank, the International Monetary Fund (IMF) and the General Agreement on Tariffs and Trade (GATT) - were established to facilitate economic growth and trade across the world. The World Bank supported projects that encouraged a global trading system, such as huge, centralised energy plants, long-distance transport networks and advanced communication systems. The IMF's role was to impose a standard economic framework for all nations and GATT worked towards ensuring that all countries depend on world trade by removing barriers to trade. In 1994, member nations of GATT created another governing body, the World Trade Organization (WTO), to set trade rules and settle disputes between nations ${ }^{(17)}$.

However, it is the wealthy industrialised nations that benefit most from globalisation ${ }^{(18,19)}$. Large transnational food companies, often based in the global north, wield the most power in WTO negotiations ${ }^{(18,19)}$. Their sheer capital base and use of horizontal and vertical integration strategies, whereby smaller, similar types of companies are purchased, as well as complementary ones, allow them to control the entire food system and dominate world markets ${ }^{(20)}$. Agricultural restructuring in recent decades has also meant that retailers and food manufacturers increasingly determine what farmers grow, providing strict specifications of their requirements in contractual arrangements, leaving farmers with less control over what they produce ${ }^{(20)}$. Supermarkets are also exerting greater control over the food production sector, by manufacturing their own 'private' label products, often sourcing cheaper raw ingredients from overseas sources, rather than locally ${ }^{(21)}$.

\section{Consequences of the current food system}

\section{Food as a commodity}

As illustrated above, the modern, globalised food system trades food as a commodity, just like any other product in the marketplace, so linking food production to a particular place which has cultural significance to a population rarely occurs $^{(3,19)}$. In parallel with this phenomenon, people are encouraged to think that their food comes from multinational companies rather than from farmers and the earth, which has resulted in an acceptance of an anonymous and homogeneous food supply that has contributed to the rise in diet-related diseases across the globe ${ }^{(3,13,22,23)}$.

\section{Intervening outcomes of the current food system}

\section{Environmental costs}

The industrialised farming practices that have been tailored to achieve maximum productivity for economic gain have led to a myriad of inadvertent environmental costs ${ }^{(1,3,15,24)}$. Approximately half of the global usable land is used by pastoral or intensive agriculture, but through land degradation, there is now a steady decline in arable land worldwide ${ }^{(1,14)}$. In countries such as the USA and Australia, where programmes to improve soil erosion have been implemented, the impact of soil erosion is still high ${ }^{(15,25)}$. Other factors impacting on soil quality are acidity and salinity, both of which impair plant growth ${ }^{(26)}$.

The modern agricultural system affects water resources. First, it diverts water from other potential uses, such as for domestic, industrial, recreational and environmental purposes $^{(1,14,27,28)}$. Second, agriculture reduces water quality, through pollution by high use of fertilizers and pesticides and through increased sediment and salt loads that occur as a result of soil erosion and salinity ${ }^{(1,4,14,24)}$. Somewhere between $30 \%$ and $50 \%$ of nitrogen fertilizers and approximately $45 \%$ of phosphorus fertilizer is taken up by crops, leaving the remainder somewhere in the environment ${ }^{(1,24)}$.

Australia's ecosystem is not very resilient to external pressures and as a result of extensive land clearing for agricultural purposes and overgrazing, biodiversity is in serious decline ${ }^{(4,29)}$. Industrial agriculture also favours using a narrow range of crop species, replacing multistrata vegetation and complex crop patterns ${ }^{(30)}$, which leads to a loss of structural diversity and causes the fragmentation of native habitats and consequently a decline in animal populations, especially invertebrate consumers, predators and pests ${ }^{(14,31-33)}$. Monocropping also relies heavily on the use of artificial pesticides to 
avoid disease and pest damage to crops, which further reduces biodiversity, as they kill wild bees and other species that are not necessarily the target organisms ${ }^{(14,34)}$. Many of the genetically uniform high-yielding crop varieties commonly used in modern agriculture are often less resistant to pathogens and pests, making them susceptible to attack by new or adapted parasites, which threatens the sustainability of the current food system ${ }^{(35,36)}$.

The final way in which modern industrialised agriculture affects the environment is through its contribution to climate change ${ }^{(4,14,37)}$. According to Intergovernmental Panel on Climate Change estimates, agriculture contributes about $10-12 \%$ of human-generated greenhouse gas emissions globally ${ }^{(38)}$. Energy use from fuel and electricity also contributes to greenhouse gas emissions from the agricultural sector $^{(38)}$. Beyond the food production section of the modern food system, the carbon emissions that are generated through transportation of food also present challenges for the current food system. The term 'food miles' is a proxy measure for the distance that food travels from paddock to plate, but in fact, the impact of food transport on the environment depends largely on the type of transportation ${ }^{(39)}$. For instance, carbon emissions generated from food transported by boat are nearly four times lower than the carbon emissions from food transported in large trucks ${ }^{(39)}$. Purchasing locally can reduce the distance that food travels, but these gains may be offset by the smaller trucks used and lower load factors ${ }^{(40)}$. Further, the carbon emissions generated by consumers driving to and from food outlets can be greater than those generated from the food production and distribution phases of the system ${ }^{(41)}$. Hence, from a purely environmental perspective, local food systems may not significantly reduce emissions from transport, unless very-low-carbon transport systems are used ${ }^{(42)}$.

\section{Social and economic costs}

Apart from these environmental costs, the social costs of our current food system are also significant. The success of farms and food businesses depends on people working together for a common purpose, which depends on the civility of society ${ }^{(11)}$. Social capital is described by Putnam as the quantity and quality of social relationships, civic participation, norms of reciprocity and trust that exist in a community, which have traditionally been high in rural communities ${ }^{(43,44)}$. However, the food system as it functions today weakens personal relationships between farmers, and between farmers and food processors and retailers, because of its competitive nature ${ }^{(11,45)}$. Australian farmers, who once prided themselves on upholding the significance of family and community obligations and being committed to rural life, are now more individualistic in response to economic rationalism ${ }^{(44)}$. To survive financially, farmers have had to sacrifice long-term sustainability for higher productivity because they are competing on world markets, making it difficult for farmers to stay viable in the industry ${ }^{(44,46)}$. Further, with a depressed agricultural economy, supporting rural industries also struggle to survive, leading to a decline in the size and vitality of rural communities and, with it, diminished social capital ${ }^{(24,44)}$. In concert with these circumstances, the globalised food system has meant that urban dwellers have become physically and socially separated from farmers ${ }^{(19)}$ and disconnected from nature, with little knowledge of the way that food is produced $^{(3)}$.

\section{Food and nutrition costs}

The impact of the current food system on non-farming families, the urban consumer, is not so direct, but equally insidious. The literature from the USA provides a comprehensive illustration of the disturbing intermediate outcomes of the globalised food system for food and nutrition. The estimated average adult energy intake in the USA in the $1970 \mathrm{~s}$ was $10.07 \mathrm{MJ} / \mathrm{d}$, but by the turn of the century this had increased to $12 \cdot 16 \mathrm{MJ} / \mathrm{d}^{(47)}$. Between 1970 and 1996, there was a $22 \%$ increase in the amount of fats and oils in the food supply, and a $23 \%$ increase in consumption of sugars and sweeteners ${ }^{(48)}$. High-fructose corn syrup (HFCS), a cheaper alternative to sucrose, now represents $40 \%$ of caloric sweeteners in food and beverages following a $1000 \%$ increase in its consumption between 1967 and 1990(49) . A diet high in HFCS may actually encourage overconsumption through mechanisms that cause a reduction in insulin and leptin release, hormones that inhibit food intake, which may be contributing to rising obesity levels ${ }^{(49)}$. Over the last decade, there has been a doubling of the number of fast-food restaurants in the USA ${ }^{(50)}$ and sales through restaurants are expected to reach \$US 604 billion in 2011, representing a 14 -fold increase since the $1970 \mathrm{~s}^{(51)}$. In a recent study, $30 \%$ of an adolescent sample reported eating fast foods on a typical day and those who consumed fast foods had higher energy and total fat intakes, drank more sweetened beverages but less milk, and ate fewer fruits and non-starchy vegetables than those who did not consume fast food ${ }^{(52)}$. Energy-dense fast foods may also undermine people's normal satiety mechanism and induce passive overconsumption ${ }^{(53)}$.

\section{System outcomes of the current food system}

\section{Obesity and chronic disease}

In 2005, there were 1.6 billion overweight people over 15 years of age and a further 400 million people who were obese, according to global estimates, with projections that there will be $2 \cdot 3$ billion overweight people and 700 million obese by $2015^{(54)}$. Recent figures show that nearly three-quarters of the adult population in the USA is classified as being above the healthy weight range ${ }^{(55)}$. In Australia, between 1995 and 2007/8, there was growth in the proportion of people who were overweight or obese, 
from $64 \%$ to $68 \%$ for men and from $49 \%$ to $55 \%$ for women $^{(56)}$. Diet-related diseases accounted for the highest mortality and morbidity levels in Australia in 2007, and they were among the top seven disease groups that accounted for nearly half of the health budget for $2004 / 5^{(57)}$.

\section{Food insecurity}

Research from both the USA and Australia has found that there are more fast-food restaurants in lower- than higher-income neighbourhoods ${ }^{(50,58)}$. It is cheap, energydense foods that are preferred by those who are food insecure, because these foods supply more energy for each dollar spent, but too much energy is consumed, and excess weight results ${ }^{(59)}$. Food retailing has changed over the past four decades, such that large supermarkets, which often provide a greater variety of fresh food more cheaply than smaller corner stores, are less accessible without car transport $^{(60-62)}$. This change in the food retailing environment has led to the development of 'food deserts', places where people experience both economic and geographical barriers to accessing healthy food ${ }^{(60,62,63)}$. Despite large supermarkets often offering a wider range of healthy foods, neighbourhoods with a larger number of small grocery stores may be better designed for walkability and social interactions, which may have other positive health benefits for residents, and should be considered in finding comprehensive solutions to food insecurity ${ }^{(64)}$.

\section{An unsustainable food system}

Hence, this globalised food system that promotes competitiveness, devalues personal relationships, discourages connections with nature and with food producers and imposes substantial environmental, social and health costs cannot remain sustainable ${ }^{(65,66)}$. None of the environmental costs that come from the production and transport of food are included in the cost of food for the consumer. It will be up to future generations to pay for these hidden externalities of our current, 'efficient' agricultural production methods ${ }^{(3,17,67)}$. The most disadvantaged in our communities will be the most vulnerable to these price pressures, so solutions must ensure that current inequities are not exacerbated.

\section{Local food systems}

There is some preliminary research on the role of local or community food systems in improving food system sustainability ${ }^{(68-71)}$, but whether community food systems can adequately address the environmental, social and health costs of the global food system is not so well established. A local or community food system is defined as ${ }^{(66)}$ :

a collaborative effort in a particular place to build more locally based, self-reliant food systems and economies - one in which sustainable food production, processing, distribution and consumption is integrated to enhance the economic, environmental and social health of a particular place. (p. 100)

Local food systems are not necessarily designed to completely isolate themselves from trade, but rather they aim to adapt local food production and markets to suit the environmental and health priorities of a community ${ }^{(72)}$. They form a viable counter-movement to the globalised food system in which local ecology, culture, trusting relationships and access to healthy food thrive ${ }^{(15,19,73)}$. Local food system models include farmers' markets, community-supported agricultural enterprises (CSA), roadside stands, box schemes, pick-your-own enterprises and community gardens ${ }^{(67,72,74,75)}$. CSA are a relatively new concept, having originated in Japan and Switzerland in the 1960s and designed to share the risks and benefits of food production between the farmer and the consumer ${ }^{(76)}$. Community gardens may be an allotment garden, where individuals have ownership, or shared spaces, where the food production is pooled among the community ${ }^{(77)}$.

\section{Intervening outcomes of local food systems}

The early discourse on the role of these local food systems came from academics reporting on their observations and interpretations of current activities in these spaces, rather than from empirical evidence ${ }^{(3,67,72,78)}$. The common themes discussed are that local food systems provide access to nutritious food for all; they help to develop bonds between farmers and their customers; allow community members to more actively participate in the food system and contribute to social cohesion; encourage satisfying social and cultural interactions around food; develop social responsibility and stewardship of local land; support biodiversity; and enhance a community's economic vitality ${ }^{(3,67,72,78)}$.

There is some evidence from local food system research that supports these views ${ }^{(68-71,79-84)}$. Farmers are motivated to join these systems for many reasons, not least of which is the desire to counteract the power of the dominant globalised food system and to model a successful, alternative community food system ${ }^{(70,71,79)}$. Other motivations include improving farm diversity, producing fresh, nutritious food that is often organic, reducing 'food miles' and building relationships with customers ${ }^{(70,79,80,85)}$. In turn, customers are motivated to participate in local food systems to purchase fresh, organic and seasonal produce, support farmers and build trusting relationships with them, and enjoy the social interactions that take place $^{(69,71,80,81,86,87)}$. One of the few studies to examine any nutritional benefits for users of local food systems found that participants reported eating more and a greater variety of vegetables and prepared more home-cooked meals than prior to joining the $\mathrm{CSA}^{(69)}$.

To date, there is a good understanding of the motivations of those selling and purchasing from local food 
systems, which includes a desire to reduce the environmental impact of food systems, but full life-cycle analyses of foods sold through these systems are needed to quantify any changes in carbon emissions that can be attributed to them. It is also unknown if those who procure food from these systems use low-carbon transport systems, such as walking, bikes or public transport. Understanding whether the social connections that occur between consumers and farmers through local food systems increases people's appreciation of food, encourages more thoughtful and healthier food choices and reduces food waste could provide important clues to finding better environmental, social and health outcomes for communities.

\section{System outcomes of local food systems}

While many of the food system projects demonstrate the interrelationship between food system sustainability and food security and the value of a just and equitable food system $^{(72,88)}$, much of the literature indicates that the demographic groups involved in acquiring their food through CSA and farmers' markets are those of mid to high socio-economic status, with some exceptions ${ }^{(69,70,80)}$. There is a danger that some local food systems may become exclusive and inward-looking, providing niche markets for expensive foods, sometimes labelled 'yuppie chow', rather than a type of local food system that focuses on equitable food access and community food security ${ }^{(81,89,90)}$. McCullum and colleagues ${ }^{(88)}$ outline a myriad of opportunities for improving community food security, which includes linking community gardens, farmers' markets and CSA to emergency food relief programmes, but it is unknown how often these opportunities are taken up. One such project, the 'Field to Family Community Food Project', an extension of a CSA, incorporates marginalised, low-income families into the broader community through their inclusion in the weekly CSA food distribution and cooking groups, but only CSA producers were interviewed and not those who are members or shareholders of the $\mathrm{CSA}^{(70)}$. The views of lowincome families about the role CSA and other local systems play in improving social inclusiveness and access to healthy foods are critical to establishing whether local food systems are effective in achieving equity ${ }^{(91)}$ and reducing the gap in health outcomes between rich and poor ${ }^{(92)}$. Public health nutritionists can play a key role in helping to design and implement local food systems that are more inclusive of all social groups.

A conceptual framework has been proposed to discuss two parallel and sometimes intersecting local food systems, which are classified as contemporary and traditional localism ${ }^{(93)}$. Traditional localism may occupy the same physical space, but a different social space to contemporary localism. Traditional localism is usually associated with community gardens or home gardening, where healthy and affordable food can be obtained.
Contemporary localism is usually manifested through farmers' markets, CSA and food cooperatives, and is concerned with freshness, support for farmers and a place to exercise commitment to sustainability issues ${ }^{(93)}$. Perhaps, given the extent of overweight and obesity globally and the detrimental environmental, economic and social effects of the current globalised food system discussed earlier, allowing these two types of localism to coexist, provided all social groupings have their needs met, will achieve more to mitigate the environmental effects of the food system and improve the nutritional and social health of communities than trying to contrive a one-size-fits-all local food system. After all, essential to the establishment and maintenance of local food systems is active participation by citizens in helping to shape the food system to their requirements, which is described as 'food citizenship' or 'food democracy' ${ }^{(94-96)}$. Public health nutritionists can have an important role in encouraging all people to become food citizens and in advocating for more democratic food systems, so that decisions relating to the food system are not left to large, corporate interests.

\section{The globalised food system and nutrition-related health outcomes: an explanatory framework}

Finding solutions to the obesity epidemic by modifying the current food supply to provide less fat, sugar and salt, legislating for tighter regulation of food industry marketing and offering lifestyle modification educational programmes are all legitimate ${ }^{(97)}$, but there may be untapped opportunities within local food systems to achieve equivalent or possibly better outcomes. Figure 1 provides a framework to explain the associations between the current globalised food system and poor nutrition-related health outcomes and direction for future research. The darker arrows indicate where the links between upstream influences on the food system and downstream system outcomes are well established in the literature. The lighter arrows indicate what is not known or where little evidence exists for the links between concepts proposed. The body of literature linking the upstream end of the food system through to the intervening outcomes is solid, as summarised in the present review. However, it is unknown whether the disconnections with nature and between farmers and consumers (intervening social and economic outcomes) affect people's food choices and subsequent levels of obesity or not. It is also unclear whether social connectedness may improve food security and food system sustainability, even though equity of access to healthy food is a well-understood critical component of socially sustainable food systems ${ }^{(91)}$. These are important relationships to understand, as closer social connections between people in the food system may influence positive food behaviours and health outcomes in ways previously unexplored. 


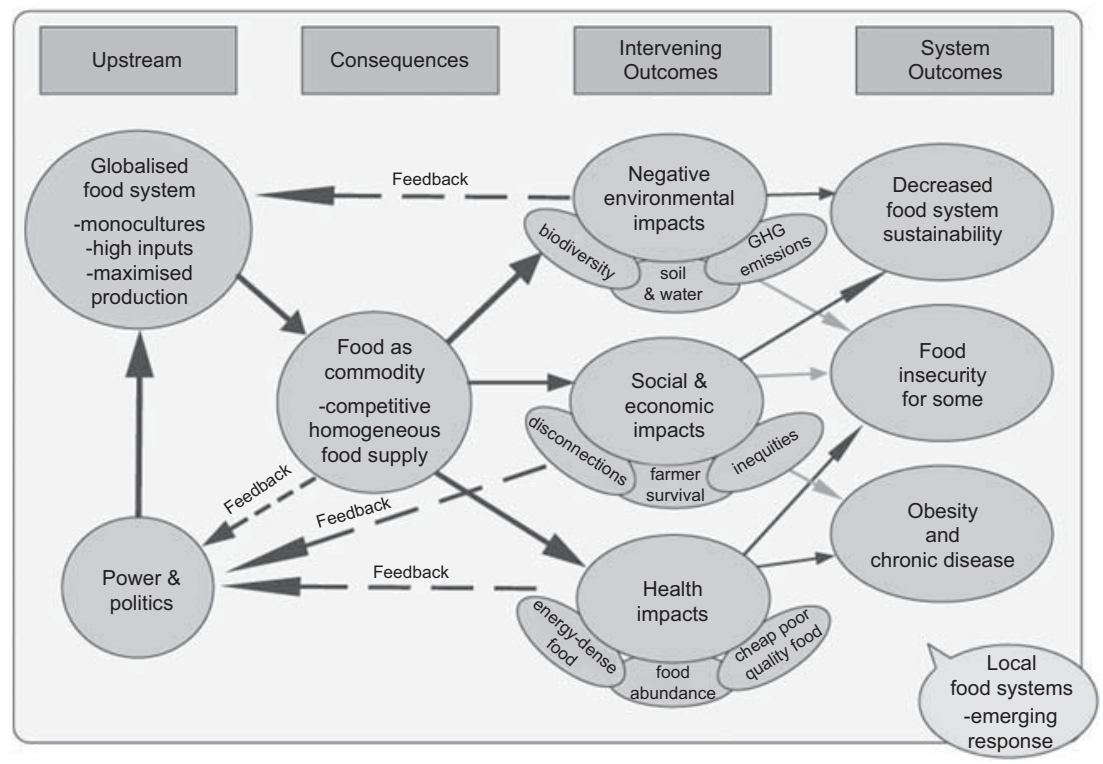

Fig. 1 The current food system (GHG, greenhouse gas)

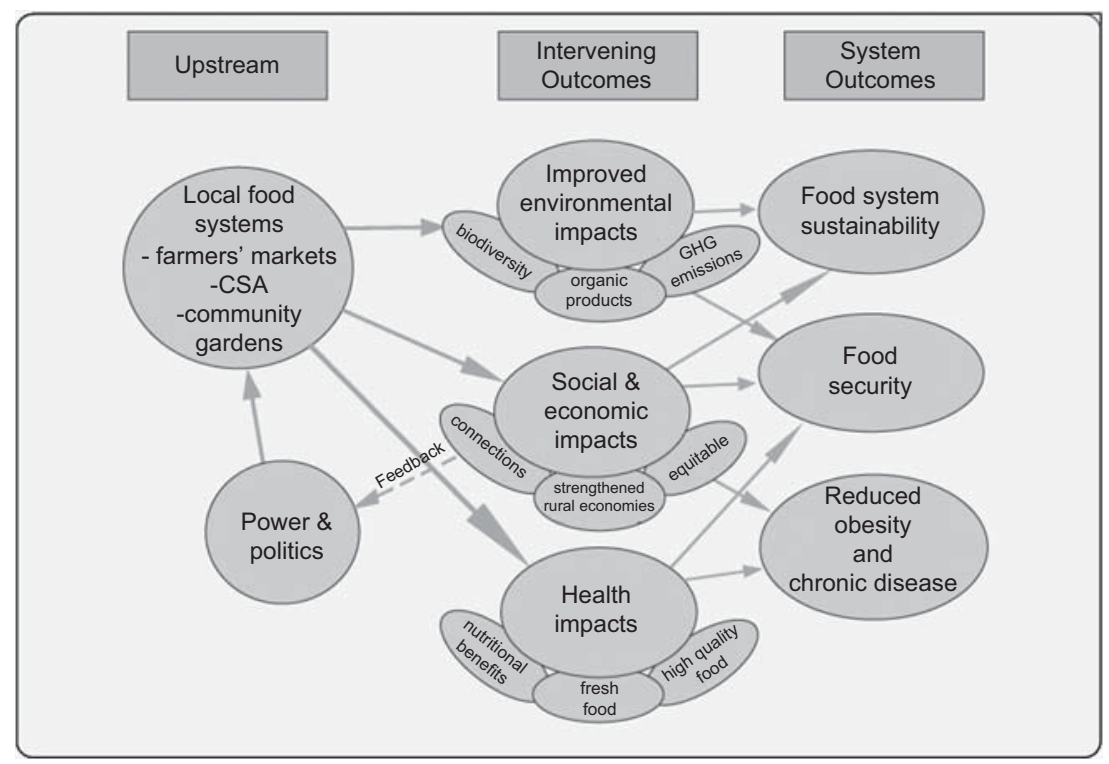

Fig. 2 Local food systems (GHG, greenhouse gas)

\section{Local food systems: the pathway to food sustainability and improved nutrition-related health outcomes?}

Similarly, Fig. 2 offers a conceptual framework to explain the links between local food systems and food system sustainability, food security and obesity. The evidence that local food systems are less detrimental to the environment than the current food system is still not clear. Organic products are common in these systems, but not exclusive ${ }^{(98,99)}$, and it is unclear whether their production and distribution systems mitigate carbon emissions ${ }^{(41)}$. Motivations for using local food systems focus on the procurement of healthy, fresh food ${ }^{(71,80,81)}$, but the evidence that better eating habits ensue is scarce. There is some support from the community garden literature that local food systems address inequities and provide solutions to food insecurity $^{(77,83,100)}$, but this is less clear in other local food system literature ${ }^{(89,90)}$. In fact, as discussed earlier, some local food systems may engender power differentials between social groups, but the evidence is somewhat insubstantial. These are important areas for public health nutrition researchers and practitioners to become engaged with, to ascertain which local food systems can best improve current inequities, eating habits and health outcomes and to advocate for optimal local food system models. 


\section{Conclusions}

The modern industrial food system produces an abundance of cheap food, but there are very costly consequences of this system for society, the environment and health. Current research indicates that local food systems may offer social, environmental and health benefits, but public health nutrition researchers need to more clearly establish the links between use of local food systems and better eating habits and reductions in obesity and chronic disease. In the interim, public health nutritionists can play a key role in supporting people to become food citizens and to advocate for democratic and sustainable food systems.

\section{Acknowledgements}

The author is part of the Faculty of Health in her working capacity as a Senior Lecturer in Nutrition and Dietetics, but for the purposes of the present paper is part of the Faculty of Education, as this is the department in which her supervisor resides. The paper has been generated from the author's PhD work and there was no funding for it, other than generous in-kind support from supervisors from the Faculty of Education and the University of Canberra. This paper is an original work and it has not been published previously, nor has it been submitted to another journal for publication. There are no conflicts of interest to report. Special thanks to the two reviewers for their thoughtful feedback and to Dr Helen Berry for her helpful suggestions regarding the re-structuring of this manuscript. Also thanks to Leigh Blackall for his technical support with the diagrams.

\section{References}

1. Tilman D, Cassman KG, Matson PA et al. (2002) Agricultural sustainability and intensive production practices. Nature 418, 671-677.

2. Coveney J (2000) Food security and sustainability: are we selling ourselves short? Asia Pac J Clin Nutr 9, Suppl. 1, S97-S100.

3. Pretty J (2002) Agri-Culture: Reconnecting People, Land and Nature. London: Earthscan.

4. Beeton R, Buckley KI, Jones GJ et al. (2006) Australia's State of the Environment 2006, Independent Report to the Australian Government Minister for the Environment and Heritage. Canberra: Department of the Environment and Heritage.

5. American Dietetic Association (2007) Position of the American Dietetic Association: food and nutrition professionals can implement practices to conserve natural resources and support ecological sustainability. J Am Diet Assoc 107, 1033-1043.

6. Sobal J, Khan LK \& Bisogni C (1998) A conceptual model of the food and nutrition system. Soc Sci Med 47, 853-863.

7. Gussow JD (1999) Dietary Guidelines for Sustainability: Twelve Years Later. Society for Nutrition Education Annual Meeting. Albuquerque, NM: Society for Nutrition Education.
8. Wahlqvist M (2005) The new nutrition science: sustainability and development. Public Health Nutr 8, 766-772.

9. McMichael AJ (2007) Will considerations of environmental sustainability revitalise the policy links between the urban environment and health? NSW Public Health Bull 18, 41-47.

10. Tilman D (1999) Global environmental impacts of agricultural expansion: the need for sustainable and efficient practices. Proc Natl Acad Sci U S A 96, 5995-6000.

11. Ikerd J (2006) Key ingredients in a sustainable food system: purpose, principles and people. Keynote address presented at 21st Annual Sustainable Agriculture Conference, Spartanburg, SC, 27-29 October 2006; available at http://web.missouri.edu/ ikerdj/papers/ South\%20Carolina\%20-\%20CFSA.htm

12. Hawkes C (2006) Uneven dietary development: linking the policies and processes of globalizatioin with the nutrition transition, obesity and diet-related chronic diseases. Global Health 2, 1-18.

13. Popkin B (1998) The nutrition transition and its health implications in lower income countries. Public Health Nutr 1, 5-21.

14. Horrigan L, Lawrence R \& Walker P (2002) How sustainable agriculture can address the environmental and human health harms of industrial agriculture. Environ Health Perspect 110, 445-455.

15. Kirschenmann FL (2008) Food as relationship. J Hunger Environ Nutr 3, 106-121.

16. Lawrence G (1999) Agri-food restructuring: a synthesis of recent Australian research. Rural Sociol 64, 186-202.

17. Norberg-Hodge H, Merrifield T \& Gorelick S (2002) Bringing the Food Economy Home: Local Alternatives to Global Agribusiness. London: Zed Books.

18. Kutting G (2004) Globalization and the Environment. Albany, NY: State University of New York Press.

19. McMichael P (2000) The power of food. Agric Human Values 17, 21-33.

20. Lawrence G \& Grice J (2008) Agribusiness, genetic engineering and the corporatisation of food. In A Sociology of Food \& Nutrition: The Social Appetite, 3rd ed., pp. 78-99 [J Germov and L Williams, editors]. Melbourne: Oxford University Press.

21. Burch D \& Goss J (1999) Global sourcing and retail chains: shifting relationships of production in Australian agri-foods. Rural Sociol 64, 334-350.

22. Caraher M \& Coveney J (2004) Public health nutrition and food policy. Public Health Nutr 7, 591-598.

23. Klein N (2001) No Logo: Taking Aim at the Brand Bullies. New York: Picador.

24. Conacher A \& Conacher J (1995) Rural Land Degradation in Australia. Melbourne: Oxford University Press.

25. National Land and Water Resources Audit (2001) Australian Agriculture Assessment 2001. Canberra: Commonwealth of Australia.

26. Mason JS (2003) Sustainable Agriculture, 2nd ed., pp. 23-31. Collingwood, VIC: Landlinks Press.

27. Ginns D (2002) The agri-food sector in Australia: where is it going? Some thoughts on the future of the sector. Australasian Agribusiness Journals - Online 54, 1-18; available at http://www.agrifood.info/perspectives/2002/

28. Pretty J (2008) Agricultural sustainability: concepts, principles and evidence. Phil Trans R Soc B 363, 447-465.

29. Sattler P \& Creighton C (2002) Australian Terrestrial Biodiversity Assessment 2002. Canberra: National Land and Water Resources Audit, Commonwealth of Australia.

30. Vandermeer J (1989) The Ecology of Intercropping. Cambridge: Cambridge University Press.

31. Chappell M \& LaValle L (2011) Food security and biodiversity: can we have both? Agric Human Values 28, 3-26. 
32. Tscharntke T, Bommarco R, Clough $\mathrm{Y}$ et al. (2007) Conservation biological control and enemy diversity on a landscape scale. Biol Control 43, 294-309.

33. Matson P \& Parton W (1997) Agricultural intensification and ecosystem properties. Science 277, 504-508.

34. Johnson B (1999) Genetically modified crops and other organisms: implications for agricultural sustainability and biodiversity. In Agricultural Biotechnology and the Poor: Proceedings of an International Conference, Washington, DC, 21-22 October 1999, pp. 131-138 [GJ Persley and MM Lantin, editors]. Washington, DC: Consultative Group on International Agricultural Research.

35. Heller MC \& Keoleian GA (2000) Life Cycle-based Sustainability Indicators for Assessment of the US Food System. Report no. 2000-4. Ann Arbor, MI: Center for Sustainable Systems, School of Natural Resources and Environment, University of Michigan.

36. Margosian M, Garrett K, Huchinson M et al. (2009) Connectivity of the American agricultural landscape: assessing the national risk of crop pest and disease spread. BioScience 59, 141-151.

37. Land and Water Australia (2008) A National Climate Change Research Strategy for Primary Industries: Phase I Report. Canberra: Land and Water.

38. Smith P, Martino D, Cai Z et al. (2007) Agriculture. In Climate Change 2007: Mitigation Contribution of Working Party III to the Fourth Assessment Report of the International Panel on Climate Change, pp. 497-540 [B Metz, O Davidson, R Bosch et al., editors]. Cambridge: Cambridge University Press.

39. Saunders C, Barber A \& Taylor G (2006) Food Miles Comparative Energy/Emissions Performance of New Zealand's Agriculture Industry. Report no. 285, Contract no. 285. Lincoln: Lincoln University.

40. Estrada-Flores S \& Larsen K (2010) Best Practice Food Distribution Systems. Melbourne: Food Chain Intelligence and Victorian Eco-Innovation Lab.

41. Foster C, Green K, Bleda M et al. (2006) Environmental Impacts of Food Production and Consumption: Final Report to the Department for Environment, Food and Rural Affairs. London: Manchester Business School.

42. Larsen K, Ryan C \& Abraham AB (2008) Sustainable and Secure Food Systems for Victoria: What do we know? What do we need to know? Melbourne: Victorian EcoInnovation Lab.

43. Putnam R (2000) Bowling Alone: The Collapse and Revival of American Community. New York: Simon \& Schuster.

44. Lawrence G (2005) Globalisation, agricultural production systems and rural restructuring. In Sustainability and Change in Rural Australia, pp. 104-120 [C Cocklin and J Dibden, editors]. Sydney: University of NSW Press.

45. Renting H \& Van Der Ploeg JD (2001) Reconnecting nature, farming and society: environmental cooperatives in the Netherlands as institutional arrangements for creating coherence. J Environ Policy Plann 3, 85-101.

46. McMichael P \& Lawrence G (2001) Globalising agriculture: structures of constraint for Australian farming. In Rurality Bites: The Social and Environmental Transformation of Rural Australia, pp. 153-164 [L Bourke and S Lockie, editors]. Annandale, NSW: Pluto Press Pty Ltd.

47. Swinburn B, Sacks G \& Ravussin E (2009) Increased food energy supply is more than sufficient to explain the US epidemic of obesity. Am J Clin Nutr 90, 1453-1456.

48. Kantor L (1999) A comparison of the US food supply with the food guide pyramid recommendations. In America's Eating Habits: Changes and Consequences, pp. 71-95 [E Frazao, editor]. Washington DC: USDA/Economics Research Service.
49. Bray GA, Nielsen SJ \& Popkin BM (2004) Consumption of high-fructose corn syrup in beverages may play a role in the epidemic of obesity. Am J Clin Nutr 79, 537-543.

50. Powell LM, Chaloupka FJ \& Bao Y (2007) The availability of fast-food and full-service restaurants in the United States: associations with neighbourhood characteristics. Am J Prev Med 33, Suppl. 4, S240-S245.

51. National Restaurant Association (2011) 2011Rrestaurant Industry Fact Sheet. Washington DC: National Restaurant Association; available at http://www.restaurant.org/ research/facts/

52. Bowman S, Gortmaker SL, Ebbeling CB et al. (2004) Effects of fast-food consumption on energy intake and diet quality among children in a national household survey. Pediatrics 113, 112-118.

53. Prentice A \& Jebb S (2003) Fast foods, energy density and obesity: a possible mechanistic link. Obes Rev 4, 187-194.

54. World Health Organization (2006) Overweight and Obesity. Fact Sheet no. 311. Geneva: WHO; available at http:// www.who.int/mediacentre/factsheets/fs311/en/index.html

55. Ogden C \& Carroll M (2010) Prevalence of Overweight, Obesity, and Extreme Obesity Among Adults: United States, Trends 1976-1980 Through 2007-2008. Atlanta, GA: National Center for Health Statistics, Centers for Disease Control and Prevention.

56. Australian Bureau of Statistics (2009) National Health Survey: Summary of Results 2007-2008. Canberra: Commonwealth of Australia.

57. Australian Bureau of Statistics (2010) Year Book Australia 2010, pp. 343-378. Canberra: Commonwealth of Australia.

58. Thornton LE, Bentley RJ \& Kavanagh AM (2009) Fast food purchasing and access to fast food restaurants: a multilevel analysis of VicLANES. Int I Behav Nutr Phys Act 6, 28.

59. Drewnowski A \& Specter S (2004) Poverty and obesity: the role of energy density and energy costs. Am J Clin Nutr 79, 6-16

60. Guy C, Clarke G \& Eyre H (2004) Food retail change and the growth of food deserts: a case study of Cardiff. Int $J$ Retail Distrib Manag 32, 72-88.

61. Nolan M, Rikard-Bell G, Mohsin M et al. (2006) Food insecurity in three socially disadvantaged localities in Sydney, Australia. Health Promot J Aust 17, 247-254.

62. O'Dwyer LA \& Coveney J (2006) Scoping supermarket availability and accessibility by socio-economic status in Adelaide. Health Promot J Aust 17, 240-246.

63. Beaumont J, Lang T, Leather S et al. (1995) Report from the Policy Sub-group to the Nutrition Task Force Low Income Project Team of the Department of Health. Hertfordshire: Institute of Grocery Distribution.

64. Moore LV \& Diez Roux AV (2006) Associations of neighborhood characteristics with the location and type of food stores. Am J Public Health 96, 325-331.

65. Bambrick H (2005) Is globalisation good for your health? J HEIA 12, 21-24.

66. Feenstra G (2002) Creating space for sustainable food systems: lessons from the field. Agric Human Values 19, 99-106.

67. Wilkins JL (1995) Seasonal and local diets: consumers' role in achieving a sustainable food system. Res Rural Sociol Dev 6, 149-166.

68. Brodt S, Feenstra G, Kozloff R et al. (2006) Farmercommunity connections and the future of ecological agriculture in California. Agric Human Values 23, 75-88.

69. Perez J, Allen P \& Brown M (2003) Community Supported Agriculture on the Central Coast: The CSA Member Experience. Santa Cruz, CA: Center for Agroecology \& Sustainable Food Systems.

70. Wells B, Gradwell S \& Yoder R (1999) Growing food, growing community: community supported agriculture in rural Iowa. Community Dev J 34, 38-46. 
71. Kirwan J (2004) Alternative strategies in the UK agro-food system: interrogating the alterity of farmers' markets. Sociol Ruralis 44, 395-415.

72. Feenstra G (1997) Local food systems and sustainable communities. Am J Altern Agric 12, 28-36.

73. Gillespie AH \& Smith LE (2008) Food decisionmaking framework: connecting sustainable food systems to health and well-being. J Hunger Environ Nutr 3, 328-346.

74. King CA (2008) Community resilience and contemporary agri-ecological systems: reconnecting people and food, and people with people. Syst Res 25, 111-124.

75. Pretty J \& Hine R (2001) Reducing Food Poverty with Sustainable Agriculture: A Summary of New Evidence. Colchester: University of Essex.

76. Hawkins T, Davies D, Hawkins P et al. (2003) Towards a Community Supported Agriculture, pp. 1-30. Brisbane: Friends of the Earth.

77. Bartolomei L, Corkery L, Judd B et al. (2003) A Bountiful Harvest: Community Gardens and Neighbourbood Renewal in Waterloo. Sydney: University of NSW Press.

78. Peters J (1997) Community food systems: working toward a sustainable future. J Am Diet Assoc 97, 955-956.

79. Sharp J, Imerman E \& Peters G (2002) Community supported agriculture (CSA): building community among farmers and non-farmers. I Extension 40, 1-9.

80. Cox R, Holloway L, Venn L et al. (2008) Common ground? Motivations for participation in a community-supported agriculture scheme. Local Environ 13, 202-218.

81. Feagan R, Morris D \& Krug K (2004) Niagara region farmers' markets: local food systems and sustainability considerations. Local Environ 9, 235-254.

82. Irvine S, Johnson L \& Peters K (1999) Community gardens and sustainable land use planning: a case-study of the Alex Wilson Community Garden. Local Environ $\mathbf{4}$, 33-46.

83. Saldivar-Tanaka \& Krasny ME (2004) Culturing community development, neighborhood open space, and civic agriculture: the case of Latino community gardens in New York City. Agric Human Values 21, 399-412.

84. Wakefield S, Yeudall F, Taron C et al. (2007) Growing urban health: community gardening in South-East Toronto. Health Promot Int 22, 92-101.
85. Griffin MR \& Frongillo EA (2003) Experiences and perspectives of farmers from Upstate New York farmers' markets. Agric Human Values 10, 189-203.

86. Archer GP (2003) Latent consumers' attitude to farmers' markets in North West England. Br Food J 105, 487-497.

87. Szmigin I, Maddock S \& Carrigan M (2003) Conceptualising community consumption: farmers' markets and the older consumer. Br Food J 105, 542-550.

88. McCullum C, Desjardins E, Kraak VI et al. (2005) Evidence-based strategies to build community food security. J Am Diet Assoc 105, 278-283.

89. Hinrichs CC (2003) The practice and politics of food system localization. J Rural Stud 19, 33-45.

90. Winter M (2003) Embeddedness, the new food economy and defensive localism. J Rural Stud 19, 23-32.

91. Allen P (1993) Connecting the social and the ecological in sustainable agriculture. In Food for the Future, pp. 1-17 [P Allen, editor]. New York: John Wiley \& Sons.

92. Baum F (editor) (2008) The New Public Health, 3rd ed. Melbourne: Oxford University Press.

93. McEntee J (2011) Contemporary and traditional localism: a conceptualisation of rural local food. Local Environ 15, 785-803.

94. Lang T (2005) Food control or food democracy? Reengaging nutrition with society and the environment. Public Health Nutr 8, 730-737.

95. Wilkins JL (2005) Eating right here: moving from consumer to food citizen. Agric Human Values 22, 269-273.

96. Hassanein N (2003) Practicing food democracy: a pragmatic politics of transformation. J Rural Stud 19, 77-86.

97. Swinburn B \& Bell C (2007) Obesity prevention. In Public Health Nutrition: From Principles to Practice, pp. 201-222 [M Lawrence and T Worsley, editors]. Crows Nest, NSW: Allen \& Unwin.

98. Kloppenburg J, Lezberg S, Master KD et al. (2000) Tasting food, tasting sustainability: defining the attributes of an alternative food system with competent, ordinary people. Hum Organ 59, 177-186.

99. Lea E (2005) Food, health, the environment and consumers' dietary choices. Nutr Diet 62, 21-25.

100. Armstrong D (2000) A survey of community gardens in upstate New York: implications for health promotion and community development. Health Place 6, 319-327. 